\title{
Metazoan parasite communities of Leporinus macrocephalus (Characiformes: Anostomidae) in cultivation systems in the western Amazon, Brazil
}

\author{
Williane M. de O. MARTINS ${ }^{*}$, Marcia C. N. JUSTO², Melissa Q. CÁRDENAS'2, Simone C. COHEN ${ }^{2}$ \\ 1 Instituto Federal do Acre, Estrada da Apadec n01192, Bairro Nova Olinda, CEP: 69980-000, Cruzeiro do Sul, Acre, Brasil. \\ 2 Instituto Oswaldo Cruz, Laboratório de Helmintos Parasitos de Peixes, Avenida Brasil nº 4365, Manguinhos, CEP: 21040-360, Rio de Janeiro, Brasil. \\ *Correspondig author: williane.martins@ifac.edu.br
}

\section{ABSTRACT}

In the Amazon, the growing demand for fish has been boosting the expansion of fish farms. However, the intensification of cultivation can generate disequilibrium in the parasite-host environment, predisposing fish to parasitic infections. The objective of this study was to evaluate the community structure of metazoan parasites in cultivation systems of piauçu, Leporinus macrocephalus, in the state of Acre, Brazil. We examined 100 specimens from a semi-intensive cultivation system (earth tanks) and 100 from an extensive system (dams). Overall 66.5\% of the hosts were parasitized. We collected 1,240 parasite specimens, classified in 15 metazoan taxa (10 monogenoidean, one digenean and four nematodes). The parasite prevalence was higher by Monogenoidea in the dams, and by Nematoda in the earth tanks. The parasitic indexes were, in general, low and varied among species. Monogeneoidea had higher values for quantitative and ecological descriptors of parasitism in the dams, while Nematoda had higher values in the earth tanks. A single species of Digenea was found in the dams, with low prevalence. No taxon was classified as central. In the dams, parasite abundance was correlated only with total fish length, while in the earth tanks, it was positively correlated with total length, weight and condition factor of fish. The endoparasite and ectoparasite infracommunities presented higher richness, dominance, diversity and evenness, respectively, in the earth tanks and in the dams. This is the first study of ecological descriptors of parasites of L. macrocephalus in the Amazon.

KEYWORDS: diversity, Digenea, Monogenoidea, Nematoda

\section{Comunidade de metazoários parasitos de Leporinus macrocephalus (Characiformes: Anostomidae) em sistemas de cultivo no oeste da Amazônia, Brasil}

\section{RESUMO}

Na Amazônia, a crescente demanda por pescado vem impulsionando a expansão da piscicultura. No entanto, a intensificação dos cultivos pode gerar desequilíbrio no sistema parasito-hospedeiro-ambiente, predispondo os peixes a infecçóes parasitárias. O objetivo deste estudo foi avaliar a estrutura das comunidades de metazoários parasitos de piauçu, Leporinus macrocephalus, em sistemas de cultivo no estado do Acre, Brasil. Foram coletados 200 peixes, sendo 100 espécimes de sistema de cultivo semi-intensivo em viveiro escavado e 100 de sistema extensivo em açude. Dos 200 hospedeiros analisados 66,5\% estavam parasitados. Foram coletados 1.240 espécimes de metazoários, classificados em quinze espécies (10 de Monogenoidea, uma de Digenea e quatro de Nematoda). A prevalência de parasitismo por Monogenoidea foi maior em açude e por Nematoda em viveiro. De forma geral, os índices de parasitismo foram baixos e variaram entre as espécies, com maiores valores dos descritores quantitativos e ecológicos do parasitismo por Monogenoidea em açude e Nematoda em viveiro. A única espécie de Digenea foi encontrada em açude e com baixa prevalência. Nenhum táxon foi classificado como central. Nos açudes, a abundância parasitária foi correlacionada apenas com o comprimento total dos hospedeiros, e nos viveiros com o comprimento total, peso e fator de condiçáo dos hospedeiros. Nos viveiros, a infracomunidade de endoparasitos apresentou os maiores índices de riqueza, dominância, diversidade e equitabilidade. Nos açudes, os ectoparasitos apresentaram os maiores índices. Este foi o primeiro registro de índices parasitários de L. macrocephalus em sistemas de cultivo na Amazônia.

PALAVRAS-CHAVE: diversidade, Digenea, Monogenoidea, Nematoda 


\section{INTRODUCTION}

Leporinus macrocephalus Garavello and Britisk 1988 (Anostomidae), known as piauçu, is native from the Prata and Paraguay river basins, and was introduced in fish farming in the 1990's in southeastern Brazil. The species has increasing commercial prospects due to its great productive capacity (Martins and Yoshitoshi 2003), being attractive for intensive and semi-intensive rearing in mono and polyculture. The species is omnivorous (Andrian et al. 1994) and adapts easily to artificial diets (Soares Júnior $e t a l .2013$ ), presenting rapid growth and good weight gain (Takahashi et al. 2004).

Fish farming in the state of Acre, in the southwestern Brazilian Amazon, is diversified and increasing in importance as an economic alternative, using both extensive and semiintensive cultivation systems. Usually, the extensive system is used by family fish farms, with limited use of feed, low stocking density and without water renewal. The semi-intensive system is more costly, using artificial rearing facilities with high stocking densities, balanced diet with intensive use of feed, water renewal and quality control, as well as other technologies.

Understanding the causal agents of parasitic diseases and the complex relationship between environmental factors and the hosts is important (Schalch and Moraes 2005). When fish cultivation systems with high stocking densities have inadequate water management, and substandard nutrition, parasitic diseases can emerge (Schalch and Moraes 2005; Zanolo and Yamamura 2006; Pavanelli et al. 2013; Zago et al. 2014), causing significant losses to production. Under intense infestations or infections, parasites can cause physiological damage to hosts, leading to death of fish in severe cases (Martins and Yoshitoshi 2003).

Studies on parasites of $L$. macrocephalus exist only for the southeastern region of Brazil. In the state of São Paulo, a prevalence of infection of $87.2 \%$ by Monogenoidea has been determined in L. macrocephalus (Tavares-Dias et al. 1999). High infection rates of $L$. macrocephalus by the nematode Goezia leporini caused symptoms such as lack of appetite, lethargy, pallidness and ascites (Martins and Yoshitoshi 2003). A reduction of hematological characteristics was also observed in L. macrocephalus parasitized by this species of Nematoda (Martins et al. 2004). In natural populations of $L$. macrocephalus, the presence of Rhinoxenus sp. and metacercariae of Digenea was reported in the upper Paraná River floodplain, although no quantitive or ecological parameters of parasitism were informed (Takemoto et al. 2009).

There is no information about parasites of $L$. macrocephalus in cultivation systems in the Amazon. Thus, the objective of the present study was to evaluate the communities and infracommunities of metazoan parasites of $L$. macrocephalus in cultivation systems in the state of Acre, in the Brazilian Amazon.

\section{MATERIALS AND METHODS}

Fingerlings of Leporinus macrocephalus were obtained from a commercial fingerling producer in the region. They were reared in two fish farms in the municipality of Cruzeiro do Sul (07037'52"S, 7240'12"W), state of Acre, Brazil, each with a different cultivation system. In both cases the fish were fed with a commercial extruded ration with $32 \%$ gross protein, and, in the fattening phase, with an extruded ration containing $28 \%$ gross protein. Also in both systems, L. macrocephalus were reared in polyculture with Prochilodus argenteus and Brycon cephalus.

In one farm the fish were reared in a semi-intensive system. They were distributed in three excavated rectangular earth tanks, on firm ground, $1.20 \mathrm{~m}$ deep, each with an area of $200 \mathrm{~m}^{2}$ and a volume of 240,000 liters, with water inlet and outlet control. Water renewal occurred gradually, with a supply of 5\% of the total volume of the tanks weekly. Water color was dingy/greenish, being dominated by grasses on the margins. Stocking density was $1 \mathrm{fish} / \mathrm{m}^{2}$ of water surface. The fish were fed twice a day.

The other farm used an extensive system. The fingerlings were distributed into two dams which formed through the accumulation of water from a stream. The dams were rectangular in shape, with irregular edges, a depth of $1.50 \mathrm{~m}$, each one with an area of $300 \mathrm{~m}^{2}$, and a volume of 450,000 liters, without water inlet and outlet control. The color of the water was dark, with grass vegetation on the margins. Stocking density was approximately $1 \mathrm{fish} / 5 \mathrm{~m}^{2}$ of water surface. In addition to the natural food produced in the environment, the fish received food supplementation once a day.

From June 2014 to December 2015 a cumulative sample of 100 adult fish were collected from the earth tanks, and 100 from the dams. The collection was carried out by the local farmers. Collection always occurred at the same time in the morning. On each sampling occasion the dissolved oxygen $\left(\mathrm{O}_{2} \mathrm{D}\right)$, hydrogenic potential $(\mathrm{pH})$, water temperature $\left(\mathrm{T}^{\circ} \mathrm{C}\right)$ and electric conductivity (EC) of the water at the collection point were measured with multiparameter equipment (Hanna Instruments, USA). Differences in the water characteristics between the two cultivation systems were analysed using ANOVA $(\mathrm{p}<0.05)$.

The collected fish were kept in thermal boxes and transported to the Fish Processing Laboratory (Laboratório de Processamento de Pescado) at the Instituto Federal do Acre, Cruzeiro do Sul Campus (Cruzeiro do Sul, Acre). The fish were weighed $(\mathrm{g})$, and measured for total legth $(\mathrm{cm})$ and necropsied. The gills, operculum and fins were examined for the presence of ectoparasites, and the gastrointestinal tract for the presence of endoparasites. 
For collection of Monogenoidea, the gills were removed and placed in bowls containing water at $65^{\circ} \mathrm{C}$ and shaken; then, alcohol was added to reach a concentration of $70 \%$. The parasites were collected under a stereoscopic microscope, fixed and stored in the same fixative. The Digenea were cold fixed in AFA (2\% glacial acetic acid, 3\% formaldehyde, and $95 \%$ of $70 \%$ alcohol), under light cover glass pressure. Nematodes were rinsed in $0.7 \% \mathrm{NaCl}$ solution and fixed in hot AFA. The material was taken to the Fish Helminth Parasite Laboratory (Laboratório de Helmintos Parasitos de Peixes - LHPP) at the Oswaldo Cruz Institute (Rio de Janeiro, Brazil) where the helminthes were processed for light microscope studies. Some specimens of Monogenoidea were mounted unstained in Hoyer's medium for study of the sclerotized parts, and others were stained with Gomori's trichrome and mounted in Canada balsam. The Digenea were stained with Langeron's alcoholic acid carmine, dehydrated by means of ethyl alcohol series, cleared using beechwood creosote and mounted in Canada balsam as permanent slides. Nematodes were clarified and mounted on semi-permanent slides in phenol $50 \%$. Specimens were studied under a light microscope Zeiss Axioscope 2 and the material was deposited at the Helminthological Collection of the Oswaldo Cruz Institute (CHIOC).

To evaluate the effect of parasitism on the development and health of the fish we determined the relative condition factor $(\mathrm{Kn})$, which is calculated from the relation between total length (Lt) and total weight (Wt) of the fish using the expression $\mathrm{P}=\mathrm{aCb}$, where $\mathrm{P}=$ total weight, $\mathrm{C}=$ total length, $a=$ intercept and $b=$ angular coefficient (Le Cren 1951). The coefficients $a$ and $b$ were estimated after logarithmic transformation of the weight and length data, and were used for the calculation of the theoretically expected values of weight. The condition factor was determined from the ratio of the observed total weight (Wt) and the estimated weight (We) as $\mathrm{Kn}=\mathrm{Wt} / \mathrm{We}$. Differences in condition factor between parasitized and non parasitized fish were evaluated using ANOVA $(\mathrm{p}<0.05)$.

The dispersion index (ID) was calculated in order to detect the distribution pattern of the parasite communities in species with a prevalence of $\geq 10 \%$ (Rózsa et al. 2000). The significance of ID for each species was tested using the $d$-statistic. The dominance of each component of the communities was determined by relative dominance (number of specimens of a species / total number of specimens of all species in the community) (Rohde et al. 1995).

As descriptors for the parasite community we calculated richness of parasite species, the Brillouin diversity index $(H B)$; Evenness $(E)$ in association with the diversity index, and the Berger-Parker dominance index (d) (Magurran 2004). We also calculated the parameters of infection as prevalence (P\%), mean intensity and parasite abundance based on Bush et al. (1997). All descriptors were compared between cultivation systems through the Mann-Whitney test (Zar 2010) at $\mathrm{p}<0.05$.

Parasite species were classified as central, secondary or satellite, according to Bush and Holmes (1986). The Spearman correlation coefficient $(r s)$ was used to determine possible correlations of parasite abundance with length, weight and the relative condition factor of the hosts $(\mathrm{p}<0.05)$.

This study was authorized by the Brazilian Institute of Environment and Renewable Natural Resources (IBAMA, license nr. 396871-1/2013).

\section{RESULTS}

Overall, 133 (66.5\%) of the 200 specimens of $L$. macrocephalus were parasitized by at least one helminth species. Forty-six hosts were parasitized by monogenoideans, 49 by nematodes, and 38 by the association of monogenoideans, nematodes and digeneans. We identified 15 helminth species, 10 belonging to Monogenoidea, one to Digenea, and four to Nematoda, with a total of 1,040 collected specimens (Table 1 ), and a mean of $9.3 \pm 16.7$ parasites/fish.

The prevalence of parasite infection was $73 \%$ in the earth tanks and $19 \%$ in the dams. Nine species were common in both systems (Table 2): Urocleidoides paradoxus Kritsky, Thatcher \& Boeger, 1986; Urocleidoides eremitus Kritsky, Thatcher \& Boeger, 1986; Jainus leporini Abdallah, Azevedo \& Luque, 2012; Tereancistrum parvus Kritsky, Thatcher \& Kayton, 1980; Dactylogyridae sp.1; Dactylogyridae sp.2. Procamallanus (Spirocamallanus) inopinatus Travassos, Artigas \& Pereira, 1928; Rhabdochona (Rhabdochona) acuminata (Molin 1860); and Goezia leporini Martins \& Yoshitoshi, 2003.

Two species of Monogenoidea were found only in the earth tanks (Tereancistrum paranaensis Karling, Lopes, Takemoto \& Pavanelli, 2014 and Kritskyia eirasi Kritsky, Thatcher \& Kayton, 1980), and four species occurred only in the dams (Dactylogyridae sp. 3; Microcotyle sp.; Prosthenhystera obesa (Diesing 1850) Travassos, 1922; and Brevimulticaecum sp., the latter in larval state).

Overall, Nematoda was the quantitavely predominant group, constituting $72.5 \%$ of the parasites collected, and also included the most prevalent species. Monogenoidea was the most diverse group, with ten species, yet all had prevalence lower than $10 \%$, with the exception of Urocleidoides paradoxus (Table 1). Digenea was the least represented group, with only two specimens of Prosthenhystera obesa.

In the earth tanks $U$. paradoxus, Procamallanus (Spirocamallanus) inopinatus, Goezia leporini and Rhabdochona (Rhabdochona) acuminata had significantly higher abundance, prevalence and mean intensity of infection, and Urocleidoides paradoxus and Urocleidoides eremitus were significantly more prevalent. In the dams Jainus leporini had significantly higher 
Table 1. Overall prevalence (P), mean intensity (MI), mean abundance (MA) and site of infection (SI) of parasites of Leporinus macrocephalus from cultivation systems in Acre State, Brazil. Values for Ml and MA are means \pm standard deviation. Collection nr indicates the deposit code of speciemns in the helminthological collection of Instituto Oswaldo Cruz.

\begin{tabular}{|c|c|c|c|c|c|}
\hline Parasites & Collection nr & $\mathrm{P}(\%)$ & Ml & MA & $\mathrm{SI}$ \\
\hline \multicolumn{6}{|l|}{ MONOGENOIDEA } \\
\hline \multicolumn{6}{|l|}{ Dactylogyridae Bychowsky, 1933} \\
\hline Urocleidoides paradoxus Kritsky, Thatcher \& Boeger, 1986 & 38674a,b; 38675, 38676, 38677 & 13.5 & $3.67 \pm 2.58$ & $0.50 \pm 0.76$ & Gills \\
\hline Urocleidoides eremitus Kritsky, Thatcher \& Boeger, 1986 & 38678,38679 a-c, 38680 & 9.5 & $2.11 \pm 1.24$ & $0.20 \pm 0.32$ & Gills \\
\hline Jainus leporini Abdallah, Azevedo \& Luque, 2012 & $38672 a-b, 38673 a-c$ & 7.0 & $6.93 \pm 5.12$ & $0.49 \pm 0.88$ & Gills \\
\hline Kritskyia eirasi Kritsky, Thatcher \& Kayton, 1980 & 38670 a,b, 38671 a,b & 1.0 & $3.00 \pm 1.00$ & $0.03 \pm 0.09$ & Kidney \\
\hline Tereancistrum parvus Kritsky, Thatcher \& Kayton, 1980 & $38681,38682 a, b$ & 9.0 & $2.61 \pm 2.30$ & $0.23 \pm 0.41$ & Gills \\
\hline $\begin{array}{l}\text { Tereancistrum paranaensis Karling, Lopes, } \\
\text { Takemoto \& Pavanelli, } 2014\end{array}$ & $38684 a, b$ & 1.5 & $4.33 \pm 2.52$ & $0.06 \pm 0.19$ & Gills \\
\hline Dactylogyridae sp.1 & & 3.0 & $4.83 \pm 2.99$ & $0.14 \pm 0.35$ & Gills \\
\hline Dactylogyridae sp.2 & & 1.0 & $1.50 \pm 0.70$ & $0.01 \pm 0.05$ & Gills \\
\hline Dactylogyridae sp.3 & & 1.5 & $1.33 \pm 0.57$ & $0.02 \pm 0.05$ & Gills \\
\hline \multicolumn{6}{|l|}{ Microcotylidae Taschenberg, 1879} \\
\hline Microcotyle sp. * & & 1.0 & 1.0 & $<0.1$ & Gills \\
\hline \multicolumn{6}{|l|}{ DIGENEA } \\
\hline \multicolumn{6}{|l|}{ Callodistomidae Odhner, 1910} \\
\hline Prosthenhystera obesa (Diesing, 1850) Travassos, 1922 & & 1.0 & 2.0 & $<0.1$ & Gall bladder \\
\hline \multicolumn{6}{|l|}{ NEMATODA } \\
\hline \multicolumn{6}{|l|}{ Camallanidae Railliet \& Henry, 1915} \\
\hline $\begin{array}{l}\text { Procamallanus (Spirocamallanus) inopinatus Travassos, } \\
\text { Artigas \& Pereira, } 1928\end{array}$ & $38,530-38,542$ & 39.0 & $4.54 \pm 3.51$ & $1.77 \pm 2.24$ & Intestine \\
\hline \multicolumn{6}{|l|}{ Rhabdochonidae Travassos, Artigas \& Pereira, 1928} \\
\hline Rhabdochona (Rhabdochona) acuminata (Molin, 1860) & $38,543-38,544$ & 12.0 & $3.42 \pm 1.95$ & $0.41 \pm 0.62$ & Intestine \\
\hline \multicolumn{6}{|l|}{ Anisakidae Railliet \& Henry, 1912} \\
\hline Goezia leporini Martins \& Yoshitoshi, 2003 & $38,523-38,529$ & 21.5 & $10.14 \pm 6.05$ & $2.18 \pm 2.93$ & Stomach \\
\hline \multicolumn{6}{|l|}{ Acanthocheilidae Wülker, 1929} \\
\hline Brevimulticaecum sp. (Larva) & 38,522 & 1.0 & $4.00 \pm 1.41$ & $0.04 \pm 0.12$ & Intestine \\
\hline
\end{tabular}

${ }^{*}$ ) Only one individual recorded.

abundance, prevalence and mean intensity of infection, and Tereancistrum parvus showed the highest values of mean intensity of infection (Table 2).

In the earth tanks, $P$. (S.) inopinatus was considered the central species ( $67 \%$ prevalence), while $G$. leporini was secondary ( $40 \%$ prevalence) and the other species were classified as satellites (Table 2). In the dams, all ecto and endoparasite species were classified as satellites (Table 2).

The components of the parasite community with prevalence $\geq 10 \%$ presented an aggregated dispersion pattern in both cultivation systems (Table 3). In the dams, the monogenoidean J. leporini was dominant, with 88 collected specimens ( $44.9 \%$ of the parasites collected), the highest value of relative dominance $(0.328)$, and a higher index of dispersion (ID=31.13; $d=64.52$ ). In the earth tanks, Urocleidoides paradoxus had the highest index of dispersion
$(\mathrm{ID}=8.13 ; d=26.11)$ and $G$. leporini the highest value of relative dominance $(0.443)$.

The dominance of endoparasites was high (Table 4), mainly owing to the relative dominance and prevalence of $P$. (S.) inopinatus and G. leporini (Tables 1 and 3). Endoparasites also had the highest index of dominance, diversity and total evenness, while ectoparasites had the highest total richness (Table 4). In the dams, ectoparasites were dominant, with highest values of richness and diversity, while in the earth tanks endoparasites had the highest indexes of richness, dominance, diversity and evenness, while the evenness indexes of ectoparasites were similar between the two systems (Table 4). Discrepancy in richness and abundance of nematode species was reflected in parasite diversity, since the more abundant communitiy determined the greatest diversity $(H=3.21 \pm 0.35)$ observed in the earth tanks (Table 4). 
Total parasite abundance was significantly correlated with total length, weight and condition factor of the hosts in the earth tanks, while it correlated significantly only with total fish length in the dams (Figure 1). There was no significant difference between parasitized and non-parasitized fish for weight, total length and condition factor in both cultivation systems, except for a marginally higher weight of nonparasitized fish in the earth tanks (Table 5).
Water temperature during the time of collection was significantly higher in the earth tanks than in the dams $\left(\mathrm{F}_{392}\right.$ $=7.06 ; \mathrm{p}<0.001)$ (dams: $27.2 \pm 2.4^{\circ} \mathrm{C}$; earth tanks: $29.1 \pm 1.6$ $\left.{ }^{\circ} \mathrm{C}\right)$. The other measured physicochemical water parameteres did not differ between the cultivation systems [dissolved oxygen (dams: $6.24 \pm 1.59 \mathrm{mg} / \mathrm{L}$; earth tanks: $6.3 \pm 1.3 \mathrm{mg} / \mathrm{L}$ ); $\mathrm{pH}$ (dams: 6.3 \pm 0.7 ; earth tanks: $6.3 \pm 0.6$ ); electrical conductivity (dams $15.89 \pm 5.46 \mathrm{mg} / \mathrm{L}$; earth tanks: $12.33 \pm 5.55 \mathrm{mg} / \mathrm{L})]$.

Table 2. Prevalence, parasite abundance and mean intensity of metazoan parasites of Leporinus macrocephalus in extensive (dams) and semi-intensive (earth tanks) cultivation systems in Acre State, Brazil. Values for abundance and intensity are means \pm standard deviation. Differences between the cultivation systems according to the Mann-Whitney test $[\mathrm{Z}(\mathrm{U})]$ were considered significant at $\mathrm{P}<0.05\left(^{\star}\right), \mathrm{P}<0.01\left(^{* *}\right)$ and $\mathrm{P}<0.001\left(^{* * *}\right)$.

\begin{tabular}{|c|c|c|c|c|c|c|c|c|c|}
\hline \multirow[b]{2}{*}{ Parasites } & \multirow[b]{2}{*}{ Dams } & \multicolumn{3}{|c|}{ Prevalence (\%) } & \multicolumn{2}{|c|}{ Parasite abundance } & \multicolumn{3}{|c|}{ Mean intensity } \\
\hline & & Earth tanks & $\mathrm{Z}(\mathrm{U})$ & Dams & Earth tanks & Z (U) & Dams & Earth tanks & $\mathrm{Z}(\mathrm{U})$ \\
\hline Urocleidoides paradoxus & 11.0 & 16.0 & $1.538^{*}$ & $0.35 \pm 0.03$ & $0.64 \pm 0.03$ & $2.763^{\star \star \star}$ & $2.91 \pm 0.28$ & $4.00 \pm 0.14$ & 0.491 \\
\hline Urocleidoides eremitus & 8.0 & 12.0 & $2.237^{*}$ & $0.11 \pm 0.06$ & $0.12 \pm 0.04$ & 1.157 & $1.38 \pm 0.09$ & $2.64 \pm 0.11$ & 1.327 \\
\hline Jainus leporini & 11.0 & 3.0 & $2.544^{* * *}$ & $0.88 \pm 0.05$ & $0.09 \pm 0.21$ & $2.088^{*}$ & $8.00 \pm 0.47$ & $3.00 \pm 0.55$ & $0.651^{*}$ \\
\hline Tereancistrum parvus & 8.0 & 10.0 & 1.515 & $0.31 \pm 0.09$ & $0.16 \pm 0.04$ & 0.286 & $3.88 \pm 0.37$ & $1.60 \pm 0.70$ & $2.221^{*}$ \\
\hline Dactylogyridae sp.1 & 5.0 & 1.0 & 1.535 & $0.31 \pm 0.09$ & $0.04 \pm 0.20$ & 1.014 & $3.87 \pm 0.38$ & $1.33 \pm 0.27$ & 0.849 \\
\hline Dactylogyridae sp.2 & 4.0 & 3.0 & 0.437 & $0.07 \pm 0.06$ & $0.05 \pm 0.01$ & 0.966 & $0.80 \pm 0.05$ & $0.71 \pm 0.04$ & 0.480 \\
\hline \multicolumn{10}{|l|}{ Nematoda } \\
\hline $\begin{array}{l}\text { Procamallanus (Spirocamallanus) } \\
\text { inopinatus }\end{array}$ & 17.0 & 67.0 & $2.552^{\star \star \star}$ & $0.17 \pm 0.04$ & $3.24 \pm 0.03$ & $1.862^{\star}$ & $2.80 \pm 0.11$ & $5.00 \pm 0.05$ & $4.184^{* * *}$ \\
\hline $\begin{array}{l}\text { Rabdochona (Rabdochona) } \\
\text { acuminata }\end{array}$ & 4.0 & 26.0 & $1.503^{*}$ & $0.04 \pm 0.01$ & $0.30 \pm 0.02$ & $3.192^{\star \star \star}$ & $2.00 \pm 0.25$ & $2.75 \pm 0.06$ & 3.020 ** \\
\hline Goezia Ieporini & 8.0 & 40.0 & $3.265^{\star * *}$ & $0.08 \pm 0.03$ & $0.39 \pm 0.05$ & $3.262^{* * *}$ & $3.25 \pm 0.09$ & $10.72 \pm 0.12$ & $0.221^{*}$ \\
\hline
\end{tabular}

Table 3. Index of dispersion (ID), $d$ statistic and relative dominance (RD) of metazoan parasites of Leporinus macrocephalus from extensive (dams) and semiintensive (earth tanks) cultivation systems in Acre State, Brazil. Species with prevalence $>10 \%$ are highlighted in bold. $\left(^{*}\right)$ Observed only in earth tanks; $\left({ }^{* *}\right)$ observed only in dams.

\begin{tabular}{|c|c|c|c|c|c|c|}
\hline \multirow[b]{2}{*}{ Parasites } & \multicolumn{3}{|c|}{ Dams } & \multicolumn{3}{|c|}{ Earth tanks } \\
\hline & ID & $d$ & $\mathrm{RD}$ & ID & $d$ & $\mathrm{RD}$ \\
\hline \multicolumn{7}{|l|}{ Monogenoidea } \\
\hline Urocleidoides paradoxus & 27.89 & 60.32 & 0.130 & 8.13 & 26.11 & 0.066 \\
\hline Urocleidoides eremitus & - & - & 0.041 & 6.67 & 22.33 & 0.030 \\
\hline Jainus Ieporini & 31.13 & 64.52 & 0.328 & - & - & 0.009 \\
\hline Kritskyia eirasi* & - & - & - & - & - & 0.006 \\
\hline Tereancistrum parvus & - & - & 0.116 & 3.05 & 3.39 & 0.016 \\
\hline Tereancistrum sp. & - & - & - & - & - & 0.013 \\
\hline Dactylogyridae sp.1 & - & - & 0.104 & - & - & 0.001 \\
\hline Dactylogyridae sp.2 & - & - & 0.007 & - & - & 0.001 \\
\hline Dactylogyridae sp.3** & - & - & 0.015 & - & - & - \\
\hline \multicolumn{7}{|l|}{ Nematoda } \\
\hline Procamallanus (S.) inopinatus & 7.21 & 23.79 & 0.156 & 4.16 & 6.30 & 0.330 \\
\hline Rabdochona (R.) acuminata & - & - & 0.011 & 4.97 & 17.37 & 0.082 \\
\hline Goezia Ieporini & - & - & 0.078 & 8.04 & 25.91 & 0.443 \\
\hline Brevimulticaecum sp.(larva) ${ }^{\star \star}$ & - & - & 0.029 & - & - & - \\
\hline
\end{tabular}


Table 4. Richness, dominance, diversity and evenness of the parasite infracommunities of Leporinus macrocephalus from extensive (dams) and semi-intensive (earth tanks) cultivation systems in Acre State, Brazil. Values are means \pm standard deviation. Differences between cultivation systems according to the MannWhitney test $[\mathrm{Z}(\mathrm{U})]$ were considered significant at $\left.\mathrm{P}<0.05\left(^{\star}\right),<0.01{ }^{* \star}\right)$ and $<0.001\left(^{\star \star \star}\right)$.

\begin{tabular}{|c|c|c|c|c|}
\hline Ectoparasites & Overall & Dams & Earth tanks & $Z(U)$ \\
\hline Richness & $2.97 \pm 1.46$ & $2.65 \pm 0.31$ & $2.36 \pm 1.21$ & $2.51^{\star *}$ \\
\hline Berger Parker dominance $(d)$ & $0.31 \pm 0.18$ & $0.60 \pm 0.05$ & $0.41 \pm 0.20$ & $2.88^{*}$ \\
\hline Brillouin diversity $(H)$ & $1.72 \pm 0.69$ & $1.69 \pm 0.26$ & $1.44 \pm 0.60$ & 4.73 \\
\hline Evenness $(J)$ & $0.91 \pm 0.02$ & $0.90 \pm 0.03$ & $0.93 \pm 0.04$ & 3.02 \\
\hline \multicolumn{5}{|l|}{ Endoparasites } \\
\hline Richness & $2.73 \pm 2.73$ & $2.52 \pm 0.81$ & $7.83 \pm 2.16$ & $17.22^{*}$ \\
\hline Berger Parker dominance $(d)$ & $0.73 \pm 0.18$ & $0.08 \pm 0.13$ & $0.92 \pm 0.30$ & $3.88^{\star * \star}$ \\
\hline Brillouin diversity $(H)$ & $3.34 \pm 0.37$ & $1.43 \pm 0.47$ & $3.21 \pm 0.35$ & $9.31^{*}$ \\
\hline Evenness $(J)$ & $0.94 \pm 0.01$ & $0.90 \pm 0.04$ & $0.95 \pm 0.01$ & $2.64^{*}$ \\
\hline
\end{tabular}
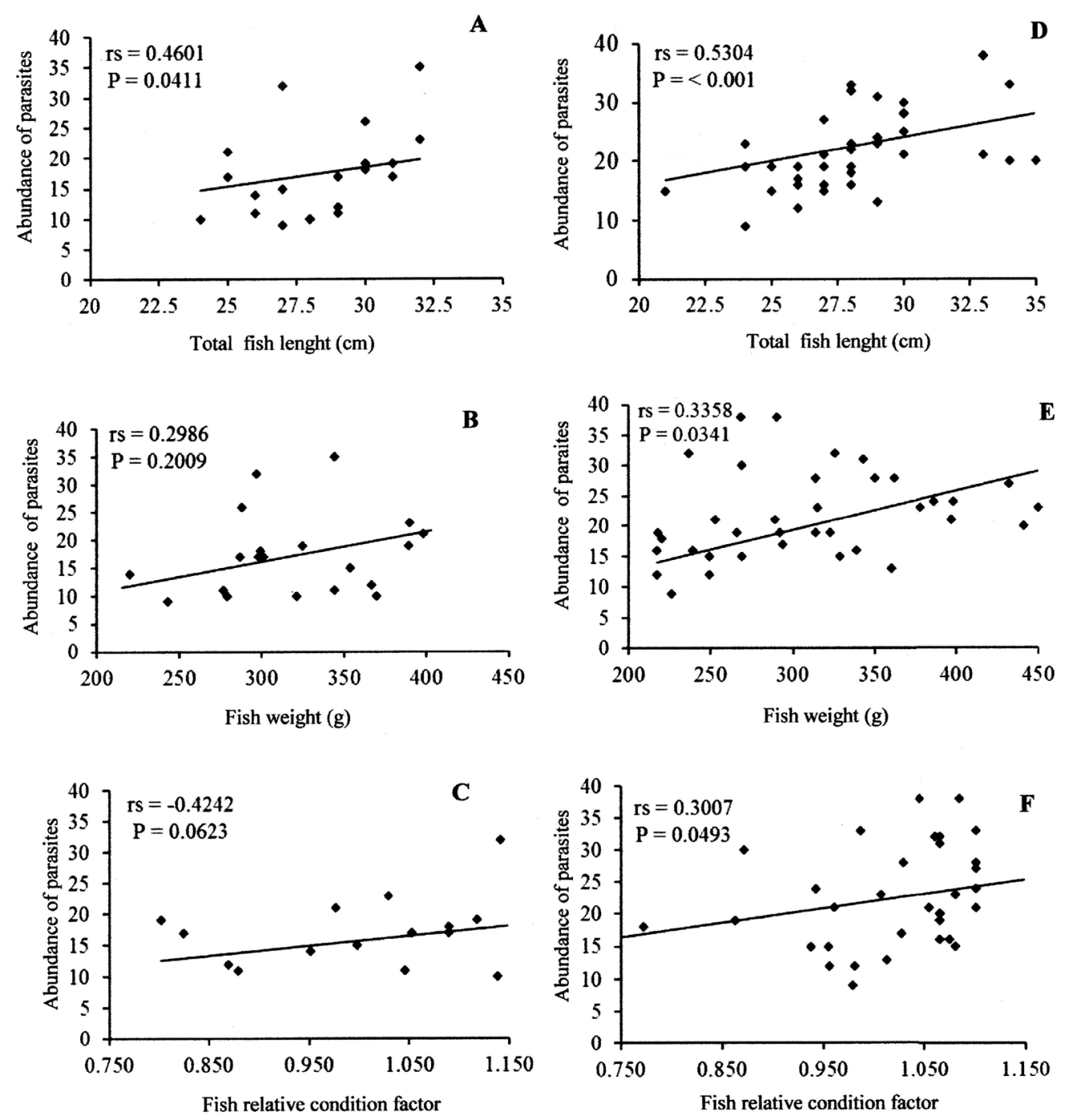

Figure 1. Spearman correlation coefficient ( $\mathrm{rs}$ ) between the abundance of parasites and total length $(\mathrm{cm})$, weight $(\mathrm{g})$ and condition factor of Leporinus macrocephalus in dams (A, B, C) and earth tanks (D, E, F) in Acre State, Brazil. 
Table 5. Weight (g), total length (cm) and condition factor of Leporinus macrocephalus in extensive (dams) and semi-intensive (earth tanks) cultivation systems in Acre State, Brazil. Values are means \pm standard deviation. Differences between the cultivation systems according to the $t$-test were considered significant at $\mathrm{P}<0.05\left({ }^{*}\right)$.

\begin{tabular}{|c|c|c|c|c|c|c|}
\hline \multirow{2}{*}{ Parameter } & \multicolumn{2}{|c|}{ Dams } & \multirow{2}{*}{$t$} & \multicolumn{2}{|c|}{ Earth tanks } & \multirow{2}{*}{$t$} \\
\hline & Parasitized & Non-parasitized & & Parasitized & Non-parasitized & \\
\hline Weight & $286.70 \pm 62.76$ & $290.65 \pm 64.27$ & 1.48 & $339.80 \pm 71.89$ & $346.02 \pm 82.27$ & $3.54^{*}$ \\
\hline Total length & $27.16 \pm 1.66$ & $28.59 \pm 2.49$ & 1.17 & $28.33 \pm 2.27$ & $29.26 \pm 1.89$ & 1.26 \\
\hline Condition factor & $0.92 \pm 0.13$ & $0.95 \pm 0.17$ & 1.69 & $0.94 \pm 0.15$ & $0.96 \pm 0.19$ & 1.33 \\
\hline
\end{tabular}

\section{DISCUSSION}

Among the six species of Monogenoidea found parasitizing L. macrocephalus in this study, only Microcotyle sp. had not been already described as parasitizing other members of the Anostomidae (Kritsky et al. 1980; Kritsky et al. 1986; Guidelli et al. 2003; Schalch and Moraes 2005; Guidelli et al. 2006; Takemoto et al. 2009; Takemoto and Lizama 2010; Abdallah et al. 2012). Some ectoparasite species that presented higher prevalence and abundance may have specificity to members of Anostomidae, such as $U$. paradoxus and T. parvus (Cohen et al. 2013). In the upper Parana River floodplain, U. paradoxus parasitized Leporinus lacustris and $L$. friderici with respective prevalences of $32 \%$ and $46.1 \%$, while Jainus spp. was the monogenoidean with higher prevalence, abundance and mean intensity in both host species (Guidelli et al. 2006). Similarly, in our study J. leporini was the monogenoid with the highest values of all parasitic indexes, except prevalence, in the dams.

The prevalence of parasites in the earth tanks in our study was similar to the prevalence reported for $L$. macrocephalus in fish farms in southeastern Brazil (65\%, Martins and Yoshitoshi 2003 , and $87 \%$, Moraes 2005). The generally higher indices of parasite prevalence, abundance and mean infection intensity observed in the earth tanks in comparison to the dams, can be explained by the higher density of fish in the earth tanks, which favors the dissemination of infectious forms of parasites (Sanches 2008).

The higher water temperature in the earth tanks, as compared to the dams, may also have contributed to the multiplication of parasites, reflecting in higher abundance and infection intensity. Water temperature is one of the key abiotic environmental factors controlling parasite dynamics in aquatic systems, which may directly influence the rates of parasite establishment, development and release of infective stages, as well as parasite transmission between hosts (Karvonen $e t$ al. 2013).
Prosthenhystera obesa was found parasitizing the gall bladder of the host. This parasite is relatively large in comparison with the size of the parasitized organ. The low prevalence of Digenea in the dams and their absence in the earth tanks was probably due to a reduced presence of their intermediate hosts. The application of calcium oxide in the surroundings of dams and earth tanks is common, which causes a reduction in the population of snails, which are intermediate hosts for these helminthes. In addition, fish farmers undertake the control of aquatic plants, thus minimizing the amount of organic waste that serves as mollusc feed.

Although the same nematode species were found in both cultivation systems (with the exception of Brevimulticaecum sp. larvae in the dams), only in the earth tanks they constituted the main component of the parasite community of $L$. macrocephalus. Among Nematoda, P. (S.) inopinatus had the highest prevalence and parasite abundance indexes. Several studies recorded an increase in the prevalence of this species in other neotropical fish, both in natural environments and in cultivation systems (Andrade and Malta 2006; Saraiva et al. 2006; Araújo et al. 2009; Gomiero et al. 2009). Procamallanus $(S$.) inopinatus was the most prevalent parasite species of Leporinus lacustris and L. friderici in the Nova Ponte Reservoir, in southeastern Brazil (Feltran et al. 2004). In the upper Parana River floodplain, in southern Brazil, the parasite had a prevalence of $20.6 \%$ in L. lacustris and $29.8 \%$ in $L$. friderici (Guidelli et al. 2006). The present study reports the first quantitative data for $P$. (S.) inopinatus parasitizing L. macrocephalus. Goezia leporini is known to parasitize L. macrocephalus in cultivation systems in São Paulo, in southeastern Brazil (Martins and Yoshitoshi 2003).

In this study, G. leporini did not show the clinical signs of disease reported by Martins and Yoshitoshi (2003). However, some specimens of $G$. leporini were attached to the gastric tract of the hosts, causing bleeding and gastric ulcers, which were reported as secondary lesions from this parasite's infection (Deardorff and Overstreet 1980). Although $G$. leporini in this study had the highest mean intensity of 
infection in both systems (10.1), they had low prevalence (21.5\%), while in southeastern Brazil prevalence was higher (65\%), with lower mean infection intensity (4.1) (Martins and Yoshitoshi 2003).

The aggregated dispersion of metazoan parasites in $L$. macrocephalus found in our study is a common pattern in parasite communities of freshwater fish in different regions of Brazil (Machado et al. 1996; Abdallah et al. 2004; Moreira et al. 2005; Paraguassú and Luque 2007; Guidelli et al. 2009; Neves et al. 2013; Tavares-Dias et al. 2013). This mode of dispersion has been associated with the direct life cycle of Monogenoidea parasites, as well as the susceptibility and capacity of immunological response of the hosts (Paraguassú and Luque 2007; Tavares-Dias et al. 2013). Dispersion values were lower for species with high prevalence, because aggregation tends to decrease as the proportion of hosts that are infected increases, and parasites spread more evenly among hosts, leaving fewer hosts uninfected (Poulin 1993).

The significant positive correlation of parasite abundance with total host length was expected since fish length is positively correlated with age, and thus larger specimens had more contact time with the infecting forms and, consequently, a greater accumulation of parasites (Luque and Chaves 1999). However, the parasitism does not necessarily increase in larger fish as a function of mechanical accumulation over a longer exposure time. For example, in Monogenoidea the positive correlation of parasite abundance with fish weight and length is likely facilitated by larger gills in larger fish, which provides more space for parasite attachment (Luque and Chaves 1999; Azevedo et al. 2007).

\section{CONCLUSIONS}

This is the first study of parasites in cultivated Leporinus macrocephalus in the state of Acre, Brazil, increasing the knowledge of the biodiversity and ecological descriptors of the parasite communities of this fish species in the Amazon region. Our results indicate that the parasite fauna of $L$. macrocephalus in extensive and semi-intensive cultivation systems in Acre does not differ very significantly. Parasitic indexes were low and varied among species, with the highest values in quantitative and ecological parasitism descriptors for Monogenoidea in the extensive, and Nematoda in the semi-intensive system. Although clinical signs of disease were not observed, parasite data suggest that prophylactic measures against future epizootic outbreaks may be indicated to avoid economic losses in fish farming due to parasitism. The occurrence of adult species of Nematoda indicated the availability of the intermediate hosts of these helminths and brings to attention the necessity of adequate sanitary control in fish farms.

\section{ACKNOWLEDGEMENT}

The study was financially supported by the Oswaldo Cruz Institute (Rio de Janeiro) and the Federal Institute of Acre (IFAC).

\section{REFERENCES}

Abdallah, V.D.; Azevedo, R.K de; Luque, J.L. 2012. Three new species of Monogenea (Platyhelminthes) parasites of fish in the Guandu river, southeastern Brazil. Acta Scientiarum. Biological Sciences, 34: 483-490.

Abdallah, V.D.; Azevedo, R.K.; Luque, J.L. 2004. Metazoários parasitos dos lambaris Astyanax bimaculatus (Linnaeus, 1758), A. parahybae Eigenman, 1908 e Oligosarcus hepsetus (Cuvier, 1829) (Osteichthyes: Characidae), do Rio Guandu, Estado do Rio de Janeiro, Brasil. Brazilian Journal of Veterinary Parasitology, 13: 57-63.

Andrade, S.M.S.; Malta, J.C.O. 2006. Fauna monitoring of Matrinxã Brycon amazonicus (Spix \& Agassiz, 1829) raised in an intensive husbandry system in a stream channel in the state of Amazonas. Brazilian Journal of Biology, 66: 1123-1132.

Andrian, I.D.F.; Dória, C.D.C. Torrente, G.; Ferretti, C.M.L. 1994. Espectro alimentar e similaridade na composição da dieta de quatro espécies de Leporinus (Characiformes, Anostomidae) do Rio Paraná, Brasil. Revista Unimar, 16: 97-106.

Araújo, C.S.O.; Gomes, A.; Tavares, D.M.; Andrade, S.M.S.; Belem, A.C.; Borges, T.B.M. 2009. Parasitic infections in pirarucu fry, Arapaima gigas Shinz, 1822 (Arapaimidae) kept in a semiintensive fish farm in Central Amazon, Brazil. Journal of the Faculty of veterinary Medicine University of Zagreb, 79: 499-507.

Azevedo, G.B.; Madi, R.R.; Ueta, M.T. 2007. Metazoans parasites of Astyanax altiparanae (Pisces: Characidae) at Rio das Pedras Farm, Campinas, SP, Brazil. Bioikos, 21: 89-96.

Bush, A.O.; Holmes, J.C. 1986. Intestinal helminths of lesser scaup ducks: an interactive community. Canadian Journal of Zoology, 64: 142-152.

Bush, A.O.; Lafferty, K.D.; Lotz, J.M.; Shostak, A.W. 1997. Parasitology meets ecology on its own terms. Journal of Parasitology, 83: 575-583.

Cohen, S.C.; Justo, M.C.N.; Kohn, A. 2013. South American Monogenoidea parasites of fishes, amphibians and reptiles. 1 st ed. Oficina de Livros, Rio de Janeiro, 663p.

Deardorff, T.I.; Overstreet, R.M. 1980. Taxonomy and biology of North American species of Goezia (Nematoda: Anisakidae) from fishes, including three news species. Proceeding Helminthology Society of Washington, 47: 192-217.

Feltran, R. de B., Marçal Júnior, O., Pinese, J.F., Takemoto, R.M. 2004. Prevalência, abundância, intensidade e amplitude de infecção de nematóides intestinais em Leporinus friderici (Bloch, 1794) e L. obtusidens (Valenciennes, 1836) (Pisces, Anostomidae), na represa de Nova Ponte (Perdizes, MG). Revista Brasileira de Zoociência, 6: 169-179. 
Gomiero, L.M.; Villares, J.G.A.; Naous, F. 2009. Reproduction of Cichla kelberi Kullander and Ferreira, 2006 introduced into an artificial lake in southeastern Brazil. Brazilian Journal of Biology, 69: $175-183$.

Guidelli, G.M.; Isaac, A.; Takemoto, R.M.; Pavanelli, G.C. 2003. Endoparasite infracommunities of Hemisorubim platyrhynchos (Valenciennes, 1840) (Pisces: Pimelodidae) of the Baía river, upper Paraná river floodplain, Brazil: specific composition and ecological aspects. Brazilian Journal of Biolology, 63: 261-268.

Guidelli, G.; Tavechio, W.L.G.; Takemoto, R.M.; Pavanelli, G.C. 2006. Fauna parasitária de parasitária de Leporinus lacustres e Leporinus friderici (Characiformes, Anostomidae) da planície de inundação do alto rio Paraná, Brasil. Acta Scientiarum Biological Sciences, 3: 281-290.

Guidelli, G.; Takemoto, R.M.; Pavanelli, G.C. 2009. Ecology of the ectoparasite infrapopulations in the nasal cavities of Leporinus lacustris (Anostomidae) from the upper Paraná river floodplain, Brazil. Acta Scientiarum. Biological Sciences, 31: 209-214.

Karvonen, A.; Kristjánsson, B.K.; Skúlason, S.; Lanki, M.; Rellstab, C. Jokela, J. 2013. Water temperature, not fish morph, determines parasite infections of sympatric Icelandic threespine sticklebacks (Gasterosteus aculeatus). Ecology and Evolution: 3: 1507-1517.

Kritsky, D.C.; Thatcher, V.E.; Boeger, W.A. 1986. Neotropical Monogenea. Revision of Urocleidoides (Dactylogyridae, Ancyrocephalinae). Proceedings of the Helminthological Society of Washington, 53: 1-37.

Kritsky, D.C.; Thatcher, V.E.; Kayton, R.J. 1980. Neotropical Monogenea. Five new species from South America with the proposal of Tereancistrum gen. n. and Trinibaculum gen. n. (Dactylogyridae: Ancyrocephalinae). Acta Amazonica, 10: 411-417.

Le Cren, E.D. 1951. The length-weight relationship and seasonal cycle in gonad weight and condition in the perch (Perca fluviatilis). Journal Animal Ecology, 20: 201-219.

Luque, J.L.; Chaves, N.D. 1999. Ecologia da comunidade de metazoários parasitos da anchova Pomatomus saltator (Linnaeus) (Osteichthyes, Pomatomidae) do litoral do estado do Rio de Janeiro, Brasil. Revista Brasileira de Zoologia, 16: 711-723.

Machado, M.H.; Pavanelli, G.C.; Takemoto, R.M. 1996. Structure and diversity of endoparasitic infracommunities and the trophic level of Psedoplatystoma corruscans and Schizodon borelli (Osteichthyes) of the high Paraná River. Memórias do Instituto Oswaldo Cruz, 91: 441- 448.

Magurran, A.E. 2004. Measuring biological diversity. 1st ed. Blackwell Publishing, Oxford. 264p.

Martins, M.L.; Tavares-Dias, M.; Fujimoto, R.Y. Onaka, E.M.; Nomura, D.T. 2004 Haematological alterations of Leporinus macrocephalus (Osteichtyes: Anostomidae) naturally infected by Goezia leporini (Nematoda: Anisakidae) in fish pond. Arquivo Brasileiro de Medicina Veterinária e Zootecnia. 56: 640-646.

Martins, M.L.; Yoshitoshi, E.R. 2003. A new nematode species Goezia leporini n. sp. (Ascaridoidea) from cultivated freshwater fish Leporinus macrocephalus (Anostomidae) in Brazil. Brazilian Journal of Biolology, 63: 497-506.

Moreira, S.T.; Ito, K.F.; Takemoto, R.M.; Pavanelli, G.C. 2005. Ecological aspects of the parasites of Iheringichthys labrosus (Lütken, 1874) (Siluriformes: Pimelodidae) in reservoirs of Paraná basin and upper Paraná floodplain, Brazil. Acta Scientiarum. Biological Sciences, 27: 317-322.

Neves, L.R.; Pereira, F.B.; Tavares-Dias, M.; Luque, J.L. 2013. Seasonal influence on the parasite fauna of a wild population of Astronotus ocellatus (Perciformes: Cichlidae) from the Brazilian Amazon. The Journal of Parasitology, 99: 718-721.

Paraguassú, A.R.; Luque, J.L. 2007. Metazoários parasitos de seis espécies de peixes do reservatório de Lajes, Estado do Rio de Janeiro, Brasil. Brazilian Journal of Veterinary Parasitology, 16: $121-128$

Pavanelli, G.C.; Takemoto, R.M. Eiras, J. da C. 2013. Parasitologia de Peixes de água doce do Brasil. 1st ed. Eduem, Maringá, 452p.

Poulin, R. 1993. The disparity between observed and uniform distributions: a new look at parasite aggregation. International Journal of Parasitology, 23: 937-944.

Rohde, K.; Hayward, C.; Heap, M. 1995. Aspects of the ecology of metazoan ectoparasites of marine fishes. International Journal for Parasitology, 25: 945-970.

Rózsa, L., Reiczigel, J., Majoros, G. 2000. Quantifying parasites in samples of hosts. The Journal of Parasitology, 86: 228-232.

Sanches EG. Controle de Neobenedenia melleni (Maccallum, 1927) (Monogenea: Capsalidae) em Garoupa-Verdadeira, Epinephelus marginatus (Lowe, 1834), cultivada em tanques-rede. 2008. Revista Brasileira de Parasitologia Veterinária, 17: 145-149.

Saraiva, A.; Silva, F.A.; Silva, A.T. 2006. Parasites of the characid fish Brycon hilarii from the River Juba, Mato Grosso, Brazil. Helminthologia, 43: 158-160.

Schalch, S.H.; Moraes, F.R. 2005. Distribuição sazonal de parasitos branquiais em diferentes espécies de peixes em pesque-pague do município de Guariba-SP, Brasil. Brazilian Journal of Veterinary Parasitology, 14: 141-146.

Soares Junior, M.S.; Caliari, M.; Pereira, D.E.P. 2013. Effect of soybean inclusion in extruded rations on performance of juvenile Piavuçu (Leporinus macrocephalus L.). Ciência Animal Brasileira, 14: 399-405.

Takahashi, L.S.; Gonçalves, F.D.; Abreu, J.S.D.; Martins, M.I.E.G.; Ferreira, A.C.M. 2004. Economic viability of the piauçu Leporinus macrocephalus (Garavello \& Britski, 1988) production. Scientia Agricola, 61: 228-233.

Takemoto, R.M.; Lizama, M.L.A.P. 2010. Helminth fauna of fishes from the upper Paraná rive floodplain, Brazil. Neotropical Helminthology, 4: 5-8.

Takemoto, R.M.; Pavanelli, G.C.; Lizama, M.A.P.; Lacerda, A.C.F; Yamada, F.H., Moreira, L.H.A.; Ceschini, T.L.; Bellay, S. 2009. Diversity of parasites of fish from the Upper Paraná River floodplain, Brazil. Brazilian Journal Biolology, 69: 691-705. 
Tavares-Dias, M.; Neves, L.R.; Pinheiro, D.A.; Oliveira, M.S.B.; Marinho, R.G.B. 2013. Parasites in Curimata cyprinoides (Characiformes: Curimatidae) from eastern Amazon, Brazil. Acta Scientiarum Biological Sciences, 35: 595-601.

Tavares-Dias, M.; Schalch, S.H.; Martins, M.L.; Silva, E.S. F.; Moraes, R.; Perecin, D. 1999. Hematologia de teleósteos brasileiros com infecção parasitária. I. Variáveis do Leporinus macrocephalus Garavelo \& Britski, 1988 (Anostomidae) e Piaractus mesopotamicus Holmberg, 1887 (Characidae). Acta Scientiarum, 21: 337-342.

Zago, A.C.; Franceschini, L.; Garcia, F.; Schalch, S.H.C.; Gozi, K.S.; Silva, R.J. da. 2014. Ectoparasites of Nile tilapia (Oreochromis niloticus) in cage farming in a hydroelectric reservoir in Brazil. Brazilian Journal of Veterinary Parasitology, 23: 171-178.

Zanolo, R.; Yamamura, M.H. 2006. Parasitas em tilápias-do-nilo criadas em sistema de tanques-rede. Semina, 27: 281-288.

Zar, J.H. 2010. Biostatistical analysis. 5th ed. Prentice Hall, New Jersey, 662p.

Received: 25/04/2017

Accepted: 23/07/2017 